\title{
Detrás del espejo de plata
}

Herman Schwarz

fotoschwarz@yahoo.com

Lima-Perú

Alicia Benavides (Arequipa, 1938) expuso su segunda individual en la galería "El ojo ajeno" del Centro de la Imagen después de 34 años. A pesar de una primera y exitosa exposición en el Centro Cultural de la Municipalidad de Miraflores el año 1985, Alicia no volvió a exponer sola en una galería hasta ahora. Y lo hizo, según confiesa, porque se trataba de un espacio donde se enseña fotografía, algo a lo que ella no tuvo acceso en su etapa formativa, porque fue autodidacta.

Descubrió la fotografía cuando tenía 33 años (5 hijos) y su vida dio un giro inesperado. Tres meses después se hizo reportera gráfica de la revista Oiga. Cuando su abuelita la vio en un noticiero

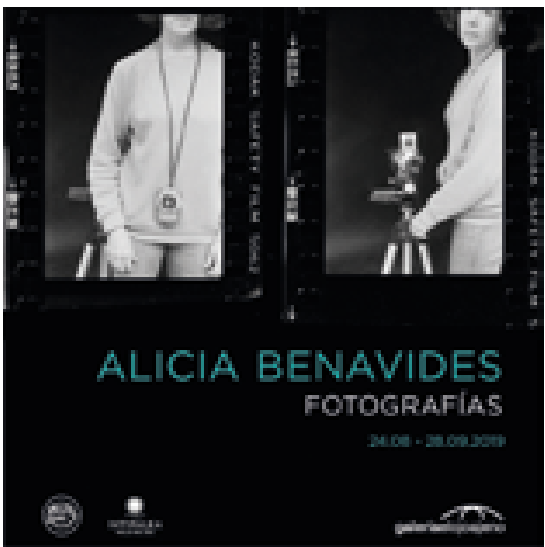
cubriendo noticias exclamó: "pobre mi nieta".

Ese fue el consenso familiar, pero ella perseveró. Fue pionera en varios sentidos, porque tuvo el valor de ejercer una profesión que solo desempeñaban hombres, convirtiéndose en una de las primeras fotorreporteras del medio, y porque se interesó en darle un rostro a la vida cultural nacional.

Tomó la posta que había iniciado Baldomero Pestana, aquel genial fotógrafo español que nos dejó una importante iconografía de nuestros intelectuales y artistas más representativos de los cincuenta y sesenta. Alicia se convirtió en las dos décadas posteriores en un referente importante de la cultura para los lectores y los fotógrafos de mi generación. Tal vez sea difícil para los jóvenes de hoy contextualizar en estos tiempos de sobreproducción de imágenes, lo que fue el acceso a éstas en aquellos años. En los setenta no habían muchos lugares donde mirar fotografías, apenas cuatro o cinco revistas de regular impresión (en papel de mala calidad) y pocos diarios dignos de mención, porque gráficamente la prensa al linotipo solo manchaba las manos. Así pues los retratos de Alicia Benavides eran una revelación semanal. Muchos aprendimos lo que era posible lograr en un retrato si prestábamos atención, algo que no estaba ni en el manejo de la luz, ni en la composición de la imagen: había una conexión con el retratado.

Esquiva a la fama y al reconocimiento, no podrá escapar a la trascendencia de sus imágenes. Sus fotografías ya son parte de nuestro imaginario colectivo. Recorrer la exposición de nuestra querida maestra Chichi Benavides es evocar una época en los rostros de nuestros creadores y de personajes anónimos que han sido retratados con la misma dignidad. Ha inmortalizado a aquellos que nos han legado parte de sus vidas en estudios históricos y textos literarios, en pintura, escultura, teatro, joyería y un largo etcétera, para la posteridad. Rostros que tienen algo de esa grandeza en la mirada, en el juego de luces y sombras a través del espejo de plata de Alicia. 